Dapat diakses pada: http://jkb.ub.ac.id/index.php/jkb/article/view/1828

Jurnal Kedokteran Brawijaya Vol. 29, No. 04, Agustus 2017, pp. 358-363

Online Published First: 31 Agustus 2017

Article History: Received 6 September 2016, Accepted 13 Januari 2017

Artikel Penelitian

\title{
Pengalaman Pasien Rawat Inap terhadap Penerapan Patient Centered Care di RS UMM
}

\section{Inpatient Experience in the Application of Patient Centered Care in UMM Hospital}

\author{
Riskiyah ${ }^{1}$, Tita Hariyanti', Siti Juhariah ${ }^{2}$ \\ ${ }^{1}$ Program Studi Pendidikan Dokter Fakultas Kedokteran dan IImu-IImu Kesehatan Universitas Islam Negeri Maulana \\ Malik Ibrahim Malang \\ ${ }^{2}$ Program Studi Magister Manajemen Rumah Sakit Fakultas Kedokteran Universitas Brawijaya Malang
}

\begin{abstract}
ABSTRAK
Patient centered care disebut juga pelayanan yang berpusat pada seseorang, berpusat pada klien, pasien dan keluarga. Berdasarkan survei kepuasan pasien dirawat inap RS UMM bulan Juli dan Agustus 2015 didapatkan data bahwa masih terdapat pasien komplain tentang sikap dan komunikasi petugas kepada pasien/keluarga yang kurang baik. Ini menandakan bahwa sikap dan komunikasi yang dilakukan oleh petugas kepada pasien maupun keluarganya kurang bagus. Artinya penerapan patient centered care belum dijalankan dengan baik. Tujuan penelitian ini adalah untuk mengeksplorasi secara mendalam pengalaman pasien selama menjalani rawat inap terhadap penerapan patient centered care yang dilakukan oleh RS UMM. Metode yang digunakan dalam penelitian ini ialah kualitatif fenomenologi. Wawancara dilakukan secara mendalam kepada 8 informan yang dianggap mewakili pasien kelas 3, 2, 1 dan kelas utama. Hasil penelitian didapatkan pengalaman yang menyenangkan tentang penerapan PCC yaitu pasien senang mendapatkan pelayanan yang ramah dan sopan dari petugas, pasien merasa dipedulikan oleh perawat selama dirawat, petugas berupaya berkomunikasi dengan baik, petugas memberikan pelayanan yang sama, petugas mengecek nama pasien ketika akan memberikan obat, makanan yang disediakan disesuaikan dengan kebutuhan dan gizi pasien. Kesimpulannya, sebagian besar pengalaman pasien rawat inap didapatkan bahwa RS UMM telah menerapkan PCC dengan cukup baik sehingga pasien merasa dikedepankan dalam proses perawatan maupun untuk memenuhi kebutuhannya.
\end{abstract}

Kata Kunci: Pengalaman pasien, patient centered care, rawat inap

\begin{abstract}
Patient centered care is also called person-centered, client-centered, and patient and family-centered services. Based on data obtained from a patient satisfaction survey in inpatient care of UMM hospital in July and August 2015 that there were patients complaining about bad attitude and bad employees communication to patients/families. These indicated that the attitude and the communication conducted by the employees to patients and their families were not good. This means that the application of patient centered care has not been implemented well. The purpose of this study is to deeply explore patients' experience during their hospitalization to the implementation of patient centered care conducted by the hospital. The method used in this study was qualitative phenomenology. In depth interviews were conducted to 8 informants considered to represent the patients on class 3, class 2, class 1 and main class. The result shows a pleasant experience on the application of PCC in which patients were happy to get a friendly service and courteous from the employees, patient felt cared by the nurses during treatment, the employees attempted to communicate well, the employees gave same service, the employees checked patient's name when giving the medication, food provided was adapted with patient's nutrition and need. In short, most inpatients' experience shows that UMM hospital has implemented PCC quite well, so patients felt prioritized in the treatment process as well as to supply their needs.
\end{abstract}

Keywords: patient experience, patient centered care, inpatient

Korespondensi: Riskiyah. Program Studi Pendidikan Dokter Fakultas Kedokteran dan IImu-IImu Kesehatan Universitas Islam Negeri Maulana Malik Ibrahim Malang, Jl Ir. Soekarno No. 34, Dadaprejo-Batu Tel. 081938695478 E-mail: riskiyah_cute@ymail.com

DOI: http://dx.doi.org/10.21776/ub.jkb.2017.029.04.13 


\section{PENDAHULUAN}

Patient Centered Care (PCC) adalah paradigma baru dalam pelayanan kesehatan yang memposisikan pasien sebagai pusat dari pelayanan (1). Konsep PCC disebut juga pelayanan yang berpusat pada seseorang, berpusat pada klien, masyarakat, pasien dan keluarga serta perawatan individual (2). Institute of Medicine (IOM) mendefinisikan patient centered care sebagai perawatan yang menghormati dan responsif terhadap pilihan, kebutuhan dan nilai-nilai yang menjamin bahwa pasien memandu semua keputusan klinis. Definisi ini menggambarkan pentingnya dokter dan pasien saling bekerja sama untuk hasil terbaik (3). Implementasi PCC tidak hanya mengutamakan teknologi, tetapi lebih memperhatikan pentingnya interaksi antar individu (1). Konsep PCC juga disebut sebagai salah satu dimensi kunci dari kualitas pelayanan kesehatan karena mengarah kepada peningkatan kepuasan pasien, pendapatan pelayanan kesehatan dan status kesehatan serta menghasilkan kepuasan kerja yang lebih besar bagi para profesional dan mengurangi tingkat kesalahan medis (4).

Implementasi PCC memerlukan kompetensi petugas dalam hal komunikasi dan penilaian, konseling dan stategi dalam perubahan berperilaku, dukungan manajemen diri terhadap penyakit dan kesehatan, serta koordinasi perawatan dengan profesional kesehatan yang lain (5). Terdapat tujuh dimensi PCC menurut Gerteis et al, yang menunjukkan bahwa sistem perawatan harus: a) menghormati nilai-nilai, pilihan dan kebutuhan pasien, b) menekankan koordinasi perawatan dan integrasi perawatan, c) menginformasikan, berkomunikasi, dan mendidik pasien serta keluarganya, d) memastikan kenyaman fisik, e) memberikan dukungan emosional, mengurangi rasa takut dan kecemasan, f) melibatkan keluarga dan teman-teman, g) mempromosikan perawatan yang berkesinambungan diantara penyedia dan institusi (2).

Sebagai perubahan paradigma, penerapan PCC bukan hal yang mudah. Berdasarkan survei kepuasan pasien rawat inap di rumah sakit (RS) tempat studi menunjukkan adanya keluhan pasien tentang komunikasi antara dokter dan pasien/keluarga kurang baik, pendaftaran pasien kurang sigap dan kurang ramah, informasi biaya operasi oleh petugas tidak sama. Keluhan tersebut mencerminkan bahwa implementasi PCC belum sepenuhnya dirasakan pasien.

Pengalaman pasien dan keluarganya saat dirawat di rumah sakit merupakan hasil interaksi antara rumah sakit dengan pelanggan. Interaksi ini mempengaruhi tidak hanya apa yang pelanggan pikirkan dan rasakan tentang rumah sakit tetapi juga kekuatan hubungan pelanggan dengan rumah sakit (6). Pengalaman pelanggan merupakan evaluasi pengalaman berharga dari kepuasan seseorang terhadap proses dan layanan jasa yang mencerminkan proses pelayanan dari sudut pandang pasien (7). Tujuan penelitian ini adalah mengeksplorasi secara mendalam pengalaman pasien selama menjalani rawat inap sebagai gambaran implementasi patient centered care di RS UMM.

\section{METODE}

Penelitian ini menggunakan metode penelitian kualitatif fenomenologi. Wawancara mendalam dilakukan kepada 8 informan yang dianggap mewakili pasien kelas 3, 2, 1, dan utama. Informan yang dipilih mewakili beberapa karakteristik antara lain jenis kelamin ada laki-laki dan wanita, cara pembayaran ada yang menggunakan BPJS (Badan Penyelenggara Jaminan Sosial) maupun membayar sendiri (umum), frekuensi dirawat, jumlah hari dirawat, kesediaan diwawancarai serta dapat menceritakan pengalamannya dengan lancar. Analisis data dilakukan dengan membuat transkripsi rekaman wawancara kemudian mereduksi data. Reduksi dilakukan dengan menentukan kalimat kunci dan kata kunci kemudian diberi kode untuk memudahkan peneliti mencari kembali jika ada data yang kurang. Setelah itu ditentukan kategori dan tema yang disusun dalam matriks etik dan emik. Etik berisi kalimat dan kata kunci yang merupakan data dari informan sedangkan emik berisi reflektif, kategori dan tema.

\section{HASIL}

Gambaran pengalaman pasien dalam penelitian ini dikelompokkan menjadi pengalaman yang menyenangkan dan tidak menyenangkan yang mencerminkan implementasi PCC dari sudut pandang pasien. Secara keseluruhan terdapat 10 tema dengan 6 tema yang menggambarkan pengalaman menyenangkan yaitu keramahan dan kesopanan, kepedulian, komunikasi yang baik, kesetaraan pelayanan, pengecekan obat, dan kesesuaian pelayanan gizi.

\section{Pelayanan yang Ramah dan Sopan dari Petugas}

Sebagian besar informan senang dengan keramahan dan kesopanan yang dimiliki oleh petugas RS baik dari dokter, petugas gizi, perawat bahkan petugas cleaning service. Semua petugas tersebut dinyatakan mempunyai sikap yang ramah, sopan, kekeluargaan, murah senyum, bertanggung jawab terhadap pekerjaannya, telaten serta setiap akan masuk maupun keluar dari kamar pasien selalu mengucapkan salam.

\section{"Ramah, murah senyum dokternya". (SP107210216.04)}

"Untuk perawatnya ramah mbak. kalo ramah saya pikir disatu sisi saya bilang kalo ada indikator, saya pikir Nilainya A. Kalo indikator saya bilang a itu segi dari pelayanan itu menurut saya sudah baik lah baik banget. Bisa di bilang sangat baik seperti itu". (T204140316.02)

"Petugas gizinya ramah, baik.. Nanyain menunya enak apa gak, apa perlu di ganti bubur atau tetep? Kalo mau ganti bilang aja gitu. Salam sapa itu juga sopan". (A108250216.05)

\section{Kepedulian oleh Perawat Selama Dirawat}

Pengalaman pasien tentang kepedulian dan perhatian perawat ditunjukkan dari beberapa perilaku antara lain: jika pasien merasakan kesulitan dan butuh bantuan dalam segala hal maka pasien diminta untuk memanggil perawat, jika dipanggil maka perawat segera datang, menjawab pertanyaan pasien dengan senang hati. Perawat selalu menanyakan keluhan informan dan jika ada pasien yang merasakan kesakitan maka perawat segera melaporkan kepada dokter yang bertanggung jawab.

"Setiap kali saya ada keluhan apa gitu, ee.. istilahnya mereka melayaninya juga dengan tersenyum". (Y203130216.03)

"Peduli. Kalo mereka di panggil itu tanggap terus mereka itu kalo ada kesakitan langsung dateng". 


\section{(A208090316.02)}

"Gati, ngopeni itu perhatian misalkan aku ada keluhan terus lapor ke dokternya". (M206090316.05)

Petugas Berupaya Berkomunikasi dengan Baik

Sebagian besar informan menyatakan petugas mempunyai komunikasi yang baik dengan pasien, misalnya dokter secara terbuka memberikan penjelasan kepada informan tentang penyakit yang diderita. Pasien juga merasa nyaman dengan komunikasi yang dilakukan dokter karena penyakit yang diderita pasien dijelaskan secara rinci. Penjelasan yang diberikan dokter dapat mengurangi beban pikiran pasien. Perawat juga memberitahu dan memberikan penjelasan kegunaan obat sebelum disuntikkan. Disamping itu, perawat sangat terbuka dalam memberikan informasi tentang obat yang akan mereka berikan kepada informan.

"Dokternya baik, dari kemarin itu dijelaskan. Bapak ini lemes karena kekurangan KCl". (B102040216.04)

"Di terangin kok mbak, enak di ajak ngobrol, istilahnya kita kalo bertanya gitu jawabannya juga rinci". (Y203130216.09)

"Dokternya jelasin kok sakitnya apa, pantangannya yang boleh di makan apa aja". (A108250216.05)

"Mau injeksi juga di terangin obatnya apa aja yang dimasukkan. Ternyata mereka terbuka kalo itu".(Y103060216.05)

"Ini obat untuk mual, antibiotik. Disuntik ya. Kalo sakit bilang". (A108250216.06)

" Bu saya mau memasukkan obat antibiotik, dijelaskanjeng". (SP107210216.08)

Pasien Senang dengan Petugas yang Memberikan Pelayanan yang Sama

Pasien menyampaikan bahwa petugas melayani informan dengan selalu memberikan senyuman dan pelayanan yang sama tanpa membedakan kelas perawatan, maupun status pembiayaan.

"Sebenarnya itu saya baru tahu ini. Tahu gitu kan saya di kelas tiga aja soalnya ternyata semua semuanya itu sama pelayanannya sama cuman yang membedakan itu hanya fasilitasnya". (S105120216.09)

"Dulu kan aku juga pernah di kelas tiga mbak, yang pertama pake umum, yang kedua pake BPJS terus ini pake BPJS lagi sama aja gak ada bedanya. Makanannya sama, dokternya sama perawatnya juga pelayanannya sama gak dibeda-bedakan. Cuman paling yang beda fasilitasnya aja". (A108250216.07)

Petugas Mengecek Nama Pasien Ketika akan Memberikan Obat

Semua pasien yang menjalani rawat inap di pasang gelang berupa gelang identitas yang warnanya dibedakan berdasarkan jenis kelamin pasien. Petugas yang akan memberikan obat baik yang diminum maupun yang disuntikkan sebelumnya menanyakan nama informan. Petugas langsung menanyakan nama ataupun memanggil informan dengan nama panggilannya. Ada juga perawat yang tidak menanyakan nama tetapi mengecek nama yang terdapat pada gelang identitas.

"lya, tiap hari diperiksa gelangnya katanya biar gak salah". (Y103060216.06)

"Gak menanyakan langsung. Sapaan jeng, bu sri ini saya mau memasukkan insulin, ngoten". (SP107210216.08)

Penerimaan Pasien terhadap Makanan yang Disesuaikan dengan Kebutuhan dan Gizi Pasien

Pasien menyatakan dapat memahami atau mengetahui bahwa mekanan yang disediakan memenuhi kebutuhan gizi atau dianggap sehat. Meskipun rasa tidak sesuai (hambar) pasien berusaha menikmani dengan tujuan agar cepat sembuh.

"Kalo menurut saya loh ya, gizinya dapat cuman kurang garem aja, hambar sedikit". (M206090316.07)

"Tak nikmati ae. Ada nasi, ada sayurnya, ada lauknya di paringi kuah. Yang saya tahu, pengetahuan saya iki wes sehat tak maem". (SP107210216.11)

"Tiap hari bubur, ya apa adanya saya makan. Ya itu tujuannya biar cepat sembuh". (B102040216.12)

Disamping pengalaman yang menyenangkan, pasien juga mengungkapkan empat tema yang tidak menyenangkan. Keempat tema tersebut ditemukan pada aspek komunikasi, waktu kedatangan dokter, keramahan dokter, dan pelayanan administrasi.

Pasien Kecewa Karena Petugas Tidak Berupaya Berkomunikasi dengan Baik

Dua responden mengungkapkan ada dokter yang tidak memberikan penjelasan secara rinci kepada pasien tentang penyakit yang dideritanya serta perawat yang tidak menginformasikan obat yang mereka berikan kepada pasien. Seorang informan mengeluhkan bahwa dokter tidak memberikan penjelasan tentang hasil USG yang telah dilakukan. Informan sudah diharuskan pulang oleh perawat sehingga tidak bisa bertemu dengan dokter untuk menanyakan hasil USG. Pada saat berkunjung dokter hanya melakukan pemeriksaan namun tidak menjelaskan secara detail tentang penyakit informan, tanpa menanyakan keluhan, dan menjelaskan pantangan dalam waktu kunjungan yang sangat pendek (3-4 menit). Ada juga perawat yang tidak mengkomunikasikan tentang jenis obat yang diberikan kepada pasien. Obat tersebut langsung disuntikkan tanpa ada pemberitahuan sebelumnya.

"Tapi kalo secara detail penyakit saya apa itu dia hanya bilang tipes terus di cek liver. Gak sampe tiga menit empat menit terus dia ke pasien lainnya. Ini dia gakmenjelaskan sama sekali". (T204140316.01)

"Langsung di suntikkan aja sama perawatnya. Semuanya gitu kok, walaupun saya pindah ruangan gitu, injeksi ya injeksi gak disebutkan ini buat apa buat apa". (S105120216.03)

\section{Kedatangan Dokteryang Tidak Tepat Waktu}

Waktu kunjungan dokter di ruang rawat inap tidak dapat dipastikan kedatangannya. Dokter akan datang untuk memeriksa pasien jika telah memiliki waktu luang. Berikut ini ungkapan informan dalam merasakan pengalaman mereka tentang waktu kunjungan dokter

"Kalo saya liat visite gak tentu. Kadang jam sepuluh, kadang jam satu. Bisa juga karena kesibukan dokter tersebut atau bagaimana saya kurang tau". 


\section{(T104080216.06)}

" Kalo dokternya kadang kala pagi, kadang kala saya masih tiduran gini, tau-tau sudah nongol dokternya. Kadang-kadang Kalo di tunggu-tunggu sampe siang jam dua baru nongol. Di tunggu mulai pagi, datengnya jam dua. Klo bisa jam delapan dateng tiap hari, lebih nyaman ke pasien. Yang nunggu juga merasa nyaman. Gak terlalu lama nunggu. Soalnya orang nunggu itu sangat capek sekali". (B102040216.06)

\section{Ketidakramahan Sikap Dokter}

Sebagian kecil informan mengeluhkan bahwa dokter yang merawat jika bertemu untuk memeriksa tidak memberikan senyuman sama sekali, berbicara dengan nada tinggi kepada pasien, bersikap masa bodoh. Dokter langsung memeriksa tanpa ada komunikasi sama sekali dengan pasien.

"Dibilangi doktere aja seng ketus, berbicara dengan nada tinggi". (I201070216.07)

"Enggak dan kalo menurut saya sih gak, soalnya ya itu cuek. Langsung meriksa, gak kamu itu harus gini gini". (S105120216.07)

\section{Kekecewaan dengan Proses Administrasi yang Lama}

Hanya satu informan yang mengeluhkan bahwa untuk proses pengurusan administrasi ketika pulang membutuhkan waktu tidak sebentar. Informan harus mengantri lama dan kurang begitu jelas mengenai proses administrasi kepulangan di RS UMM

"Waktu mau pulang proses administrasinya agak lama. Nunggu proses antri gitu. Ini masih numpuk bu, gitu. Sebenere gak boleh gitu ya. Nanti malah rumah sakit sendiri yang kena ya. Proses lama kan ngapokno orang ya, kalo pulang lama. Ya cuman penanganane bagus. Pulang itu tok gak tau antriannya gimana". (A2SU08090316.01)

\section{DISKUSI}

Penelitian ini mengidentifikasi sepuluh tema pengalaman pasien yang sebagian besar merupakan pengalaman menyenangkan bagi pasien yang mengindikasikan pemenuhan implementasi pelayanan yang berfokus pada pasien. Pengalaman menyenangkan yang mencerminkan penerapan PCC diantaranya keramahan dan kesopanan, kepedulian, komunikasi yang baik, kecepatan, mekanisme klarifikasi dan konfirmasi, dan kesesuaian makanan dengan kebutuhan dan gizi pasien. Disisi lain pasien juga menggambarkan pengalaman yang tidak menyenangkankan dalam hal komunikasi, kedatangan dokter yang tidak tepat waktu, ketidakramahan dokter, dan waktu pelayanan administrasi yang lama.

Pasien melaporkan pelayanan yang ramah dan sopan dari petugas baik itu dokter, perawat, petugas gizi bahkan petugas cleaning service. Baboo, et al, dalam kajiannya tentang persepsi perawat profesional mengenai PCC menemukan bahwa keterampilan komunikasi adalah komponen dari PCC yang dilihat atau diamati oleh pasien. Oleh karena itu perawat harus berbicara dengan nada lembut kepada pasien, tidak berteriak dan bersikap ramah. Wajah ramah perawat membuat pasien menjadi rileks (8). Cara berkomunikasi petugas termasuk dokter merupakan komponen yang membentuk keramahan dan menjadi penentu dari kesembuhan seorang pasien (9).

Pasien merasa dilayani dan dipedulikan oleh perawat karena perawat selalu datang ketika pasien membutuhkan bantuan. Bentuk pelayanan psikologis yang memberikan pelayanan kepada pasien berdasarkan rasa simpatik dan empati diantaranya adalah segera melakukan tindakan perawatan ketika pasien menyampaikan keluhan, membantu pasien dalam proses pemulihan, memberikan kenyamanan bagi pasien dalam memenuhi kebutuhannya untuk minum obat dan makan secara teratur (10). Hal ini sesuai dengan dimensi PCC yaitu mengetahui tentang kemajuan pasien dan bertanggung jawab terhadap kebutuhan mereka, pasien berpartisipasi dalam rencana perawatan, memberikan informasi tentang kondisi dan pengobatan serta merawat pasien dengan peduli (11).

Pengalaman yang lain adalah adanya komunikasi yang baik dari petugas baik itu dari dokter maupun perawat. Pemberian informasi dan edukasi adalah merupakan bagian penting dalam PCC (12). Komunikasi dokter dan pasien telah terbukti membawa pengaruh pada kepatuhan pengobatan, meningkatkan kepuasan pasien dan akhirnya membawa manfaat bagi out put pengobatan (13). Perawat juga harus memiliki pengetahuan dan keterampilan khusus dalam memberitahukan informasi kepada pasien, sehingga dapat memberikan informasi tentang diagnosa medis, prosedur dan proses terapi ke dalam bahasa pasien yang mudah dipahami dan diterapkan (14).

Kesetaraan pelayanan juga merupakan pengalaman yang diidentifikasi pasien. Marti, Andarini, dan Lestari mengidentifikasi menghargai harkat dan martabat pasien dan keluarga pada saat proses resusitasi di IGD merupakan salah satu dimensi PCC yang diharapkan pasien. Sikap menghargai pasien ditunjukkan dengan memberikan perlakuan yang sama untuk semua pasien (12). Keinginan masyarakat terhadap kualitas pelayanan di rumah sakit tidak hanya pada pemberian layanan yang baik tetapi pelayanan yang adil dari rumah sakit $(15,16)$.

Proses klarifikasi dengan pemeriksaan ulang nama pasien ketika akan memberikan obat merupakan tindakan yang dilakukan petugas untuk membuat pasien merasa aman dan nyaman. Hal ini merupakan bentuk penerapan PCC untuk menjamin keselamatan pasien agar petugas tidak salah ketika melakukan tindakan. Salah satu langkah dalam memberikan obat kepada pasien adalah memastikan identitas pasien dengan memeriksa gelang identitas, papan identitas di tempat tidur (17). Keselamatan pengobatan juga merupakan salah satu sasaran keselamatan pasien yang diterapkan dalam standar akreditasi rumah sakit (18).

Pasien dapat menerima penyediaan makanan yang disesuaikan dengan kebutuhan dan gizi pasien. Pelayanan gizi rumah sakit merupakan sub sistem pelayanan kesehatan paripurna yang mempunyai peranan penting dalam mempercepat pencapaian tingkat kesehatan pasien baik bersifat promotif, preventif, kuratif maupun rehabilitatif (19). Pemberian gizi yang tidak adekuat dapat mengakibatkan keadaan kurang gizi yang dapat meningkatkan morbiditas dan mortalitas (20).

Meskipun hampir semua pasien menyampaikan pengalaman yang menyenangkan, pada saat yang sama masih terdapat hal-hal yang menimbulkan pengalaman tidak menyenangkan diantaranya komunikasi yang kurang baik, dokter yang kurang ramah, ketidakpastian waktu 
kunjungan dokter, dan pelayanan administrasi. Pasien kecewa ketika dokter tidak memberikan penjelasan secara rinci tentang penyakit pasien serta perawat yang tidak memberitahukan tentang obat yang diberikan. Penelitian lain juga menemukan bawa hal yang dikeluhkan oleh pasien adalah kurangnya komunikasi oleh petugas medis sehingga perkembangan penyakit pasien menjadi tidak jelas. Komunikasi yang tidak baik dapat menyebabkan terjadinya kesalahan atau kelambatan dalam mendiagnosa penyakit pasien (21). Kaharuddin juga mengidentifikasi bahwa sebagian besar responden pasien menilai dokter masih kurang baik dalam memberikan dan menjelaskan informasi kepada pasien (22). Komunikasi yang baik sangat penting bagi petugas kesehatan karena akan menjalin hubungan yang kuat dengan pasien dan menjaga keselamatan pasien (17). Salah satu strategi komunikasi yang dapat digunakan adalah 10 benar pemberian obat yaitu benar pasien, rute atau jalur, obat, dosis, waktu, pengkajian, informasi, kadaluarsa, evaluasi dan dokumentasi. Pada aspek benar informasi perawat dan petugas kesehatan harus memberikan informasi terkait nama obat, menjelaskan cara pemberian obat dan menjelaskan fungsi atau kerja obat (17).

Selain komunikasi yang kurang baik, pengalaman yang tidak menyenangkan lainnya adalah sikap dokter yang tidak ramah. Hubungan dokter dengan pasien termasuk kedalam perawatan yang berpusat kepada pasien. Hubungan yang baik ini menghasilkan kepuasan kepada pasien selama perawatan bahkan mengurangi ketakutan, kecemasan serta kekhawatiran pasien. Sebaliknya, hubungan interpersonal yang buruk dan diskriminasi terhadap pasien berpotensi mengakibatkan ketidakpatuhan terhadap pengobatan (23). Selain itu sikap petugas yang kasar dan tidak acuh dapat mengurangi kepuasan pasien terhadap pelayanan yang diterimanya (9).

\section{DAFTAR PUSTAKA}

1. Rusmawati A. Upaya Meningkatkan Kemampuan Perawat dalam Menerapkan Patient Centered Care (PCC) di Rumah Sakit (Studi di RSUD Dr. Harjono Ponorogo dan RSUD Dr. Iskak Tulungagung). [Thesis]. Universitas Diponegoro, Semarang. 2016

2. Bleich MR. Patient-Centered Leadership. The Journal of Continuing Education in Nursing. 2015; 46(7): 297-298.

3. Barry MJ dan Levitan SE. Shared Decision MakingThe Pinnacle of Patient-Centered Care. The New England Journal of Medicine. 2012; 366(9): 780-781.

4. Mills I, Frost J, Moles DR, dan Kay E. Patient-Centred Care in General Dental Practice: Sound Sense or Soundbite? British Dental Journal. 2013; 215(2): 8185.

5. Ghebrehiwet T. Nurses and Person-Centred Care. The International Journal of Person Centered Medicine. 2011; 1(1): 20-22.

6. Sirapracha J dan Tocquer G. 'Customer Experience, Brand Image and Customer Loyalty in Telecommunication Services'. International Conference on Economics, Business and Marketing
Kedatangan dokter yang tidak tepat waktu dapat membuat pasien merasa kecewa. Waktu kunjungan dokter yang tidak teratur dan tidak pasti ini membuat pasien harus menunggu untuk waktu yang tidak jelas dan bisa membuat pasien merasa cemas karena jika ada keluhan tentang sakitnya yang ingin segera disampaikan kepada dokter harus tertunda. Penelitian yang dilakukan oleh David et al, menunjukkan bahwa keterlambatan waktu kedatangan dokter dalam memberikan pelayanan mempengaruhi kepuasaan pasien di rumah sakit (24). Ketepatan waktu dalam pelayanan merupakan kemampuan rumah sakit memberikan pelayanan sesuai dengan yang dijanjikan, yaitu meliputi kecepatan dan ketepatan petugas didalam memberikan pelayanan meliputi: ketepatan dalam prosedur penerimaan pasien, pendaftaran, waktu menunggu, waktu diperiksa dan mendiagnosa penyakit serta kesembuhan penyakit (25).

Hanya satu pasien yang merasa kecewa tentang proses administrasi ketika akan pulang dikarenakan lama dan pasien masih harus menunggu antrian. Sureshchandar et al, dalam penelitiannya menyatakan bahwa proses pelayanan harus sempurna berdasarkan pada standarisasi dan tingkat efisien serta disederhanakan untuk pasien sehingga pasien menerima layanan tidak merasa kesulitan karena dimudahkan dalam segala urusan (26). Prosedur pelayanan yang tidak berbelit-belit memberikan kontribusi cukup besar terhadap kepuasan pasien (9). Sebagai perwujudan pelayanan publik yang baik rumah sakit harus memberikan pelayanan yang mudah, wajar, tanpa pilih kasih, serta dilandasi kejujuran dan keterbukaan (27).

Penelitian ini mengidentifikasi tema pengalaman pasien yang mencerminkan bahwa belum semua penerapan aspek PCC telah sepenuhnya dirasakan oleh pasien. Komunikasi dan keramahan petugas menjadi satu aspek yang dapat menjadi sumber pengalaman menyenangkan sekaligus tidak menyenangkan.

Management. 2012; 29(3): 112-117.

7. Wijaithammarit $\mathrm{S}$ dan Taechamaneestit $\mathrm{T}$. The Impact of Customer Experience Management on Customer Loyalty of Supercenter's Shopper in Thailand. International Journal of e-Education, eBusiness, e-Management and e-Learning. 2012; 2(6): 473-477.

8. Jardien-Baboo S, Rooyen D, Ricks E, dan Jordan P. Perceptions of Patient-Centred Care at Public Hospitals in Nelson Mandela Bay. Health SA Gesondheid. 2016; 21(1): 397-405.

9. Azkha N dan Elnovriza D. Analisis Tingkat Kepuasan Klien terhadap Pelayanan Kesehatan di Puskesmas dalam Wilayah Kota Padang Tahun 2006. Jurnal Kesehatan Masyarakat Andalas. 2007; 1(2): 65-72.

10. Rusdiana. Studi tentang Pelayanan Perawat terhadap Kepuasan Pasien di Ruang Rawat Inap Mawar Rumah Sakit Umum Abdul Wahab Sjahranie Samarinda. e Journal Konsentrasi Sosiologi. 2014; 2(4): 13-25.

11. Poochikian-Sarkissian S, Sidani S, Ferguson-Pare M, Doran D. Examining the Relationship Between Patient-Centred Care and Outcomes. Canadian Journal of Neuroscience Nursing. 2010; 32(4): 14-21. 
12. Marti E, Andarini S, dan Lestari R. Studi Fenomenologi Penerapan Prinsip Patient Centered Care pada Saat Proses Resusitasi di IGD Rsud Saiful Anwar Malang. The Indonesian Journal of Health Science. 2015; 6(1): 73-89.

13. Salawati L. Tingkat kepuasan Pasien Jamkesmas di Ruang Rawat Inap Penyakit Dalam Rumah Sakit Umum Daerah DR. Zainoel Abidin Banda Aceh. Jurnal Kedokteran Syiah Kuala. 2012; 12(2): 75-80.

14. Afidah EN dan Sulisno M. Gambaran Pelaksanaan Peran Advokat Perawat di Rumah Sakit Negeri di Kabupaten Semarang. Jurnal Manajemen Keperawatan. 2013; 1(2): 124-130.

15. Padma P, Rajendran C, dan Sai L. A Conceptual Framework of Service Quality in Health Care: Perspectives of Indian Patients and Their Attendants. Benchmarking: An International Journal. 2009; 16(2): 157-191.

16. Hidayati AN, Suryawati C, dan Sriatmi A. Analisis Hubungan Karakteristik Pasien dengan Kepuasan Pelayanan Rawat Jalan Semarang Eye Center (SEC) Rumah Sakit Islam Sultan Agung Semarang. Jurnal Kesehatan Masyarakat (e-Journal). 2014; 2(1): 9-14.

17. Fatimah FS dan Rosa EM. Efektivitas Pelatihan Patient Safety, Komunikasi S-BAR pada perawat dalam Menurunkan Kesalahan Pemberian Obat Injeksi di Rumah sakit PKU Muhammadiyah Yogyakarta Unit II. Journal NERS \& Midwifery Indonesia. 2014; 2(1): 32-41.

18. Harianto JW, Nursalam, dan Dewi YS. Keselamatan Pasien Berbasis Knowledge Management Seci sebagai Peningkatan Kompetensi Mahasiswa Keperawatan. Jurnal Ners. 2015; 10(2): 324-331.

19. Puruhita N, Hagnyonowati, Adianto S, Murbawani EA, dan Ardiaria M. Gambaran Sisa Makanan dan Mutu Makanan yang Disediakan Instalasi Gizi Rumah Sakit Umum Pusat Dr. Kariadi Semarang. Journal of Nutrition an Health. 2014; 2(3): 1-14
20. Semedi P, Kartasurya MI, dan Hagnyonowati. Hubungan Kepuasan Pelayanan Makanan Rumah Sakit dan Asupan Makanan dengan Perubahan Status Gizi Pasien (Studi di RSUD Sunan Kalijaga Kabupaten Demak). Jurnal Gizi Indonesia. 2013; 2(1): 34-38.

21. Ratnamiasih I, Govindaraju R, Prihartono B, dan Sudirman I. Analisis Kualitas Layanan pada Bagian Rawat Inap Rumah Sakit di Bandung. Trikonomika. 2013; 12(2): 134-144.

22. Kaharuddin A. Perbandingan Kualitas Patient Engagement pada Empat Pelayanan Spesialis Dasar di RSUD Haji Provinsi Sulawesi Selatan. Jurnal Al Hikmah. 2014; 15(1): 43-53.

23. Atinga R, Bawolea JN, dan Nang-Beifubah, A. Some Patients are More Equal than Others: PatientCentred Care Differential in Two-Tier Inpatient Ward Hospitals in Ghana. Patient Education and Counseling. 2016; 99(3): 370-377.

24. David, Hariyanti T, dan Widayanti E. Hubungan Keterlambatan Kedatangan Dokter terhadap Kepuasaan Pasien di Instalasi Rawat Jalan. Jurnal kedokteran Brawijaya. 2014; 28(1): 31-35.

25. Mukti WY, Hamzah A, dan Nyorong M. Pengaruh Mutu Layanan Kesehatan terhadap Kepuasan Pasien Rawat Inap di Rumah Sakit Woodward Kota Palu. Jurnal Administrasi dan Kebijakan Kesehatan. 2013; 2(3): 35-41.

26. Sureshchandar GS, Chandrasekharan R, dan Anantharanan R. Determinants of Customer, Perceived Service Quality: A Confirmatory Factor Analysis Approach. Journal of Services Marketing. 2002; 16(1): 9-34.

27. Suryani W. Pengaruh Pelayanan terhadap Kepuasan Pasien Rawat Inap pada Rumah Sakit Umum Pirngadi Medan. Jurnal Implementasi Ekonomi dan Bisnis. 2015; 4(1): 819-838. 